\title{
Od Verne'a do Tulleta. Sto lat obecności francuskiej literatury dla dzieci i młodzieży na polskim rynku książki
}

\author{
Paprocka, N. (2018). Bibliografia polskich przekładów i adaptacji \\ francuskiej literatury dla dzieci i młodzieży wydanych w latach \\ 1918-2014. Kraków: TAiWPN Universitas.
}

Paprocka, N. (2018). Sto lat przekładów dla dzieci i młodzieży w Polsce. Francuska literatura dla młodych czytelników, jej polscy wydawcy i ich strategie (1918-2014). Kraków: TAiWPN Universitas.

\section{Abstrakt:}

W artykule recenzyjnym omówione zostały dwie książki Natalii Paprockiej (2018): Bibliografia polskich przekładów i adaptacji francuskiej literatury dla dzieci i młodzie$\dot{z} y$ wydanych $w$ latach 1918-2014 oraz Sto lat przekładów dla dzieci i młodzieży w Polsce. Francuska literatura dla młodych czytelników, jej polscy wydawcy i ich strategie (1918-2014), wpisujące się zarówno w kontekst translatoryki literatury dziecięcej, jak i bibliologii oraz socjologii sztuki. W artykule scharakteryzowano układ zestawionej przez Natalię Paprocką bibliografii polskich przekładów francuskiej literatury dla dzieci i młodzieży oraz streszczono najważniejsze założenia jej badań: wykorzystano w nich koncepcję pola literackiego Pierre'a Bourdieu, pojęcia importu/transferu i repertuaru kulturowego w rozumieniu Itamara Evena-Zohara oraz teorię aktora-sieci Brunona Latoura. Według badaczki w ciągu całego stulecia wśród polskich wydawców dominowała polityka wznowień klasyki, co pociągnęło za sobą bardzo ograniczony transfer zjawisk innowacyjnych we francuskiej kulturze dziecięcej.

\section{Słowa kluczowe:}

agent, bibliografia, Francja, ilustracja książkowa dla dzieci, literatura dziecięca i młodzieżowa, literatura francuska, Natalia Paprocka, pole literackie, Polska, przekład, recepcja, repertuar kulturowy, ruch literacki, tłumacz, transfer, wydawca

* Joanna Frużyńska - dr, pracuje w Instytucie Polonistyki Stosowanej na Wydziale Polonistyki Uniwersytetu Warszawskiego. Jej zainteresowania obejmują literaturę dziecięcą i kulturę popularną, zwłaszcza powieść kryminalną, a także różne formy sztuki adresowanej do młodych odbiorców. Kontakt: j.fruzynska@uw.edu.pl. 


\title{
From Verne to Tullet: A Century of French Children's and Young Adult Literature on the Polish Book Market
}

\author{
Paprocka, N. (2018). Bibliografia polskich przekładów i adaptacji francuskiej \\ literatury dla dzieci i młodzieży wydanych w latach 1918-2014. Kraków: \\ TAiWPN Universitas.
}

Paprocka, N. (2018). Sto lat przekładów dla dzieci i młodzieży w Polsce. Francuska literatura dla młodych czytelników, jej polscy wydawcy i ich strategie (1918-2014). Kraków: TAiWPN Universitas.

\section{Abstract:}

This review article discusses two books by Natalia Paprocka (2018): Bibliografia polskich przekładów i adaptacji francuskiej literatury dla dzieci i młodzieży wydanych w latach 1918-2014 [Bibliography of Polish Translations and Adaptations of French Literature for Children and Youth Published in the Years 1918-2014] and Sto lat przekładów dla dzieci i młodzieży w Polsce. Francuska literatura dla młodych czytelników, jej polscy wydawcy i ich strategie (1918-2014) [A Hundred Years of Translations for Children and Youth in Poland: French Literature for Young Readers, its Polish Publishers and Their Strategies (1918-2014)], which belong to the field of children's literature translation studies, bibliology, and sociology of art. The article describes the arrangement of the bibliography of Polish translations of French literature for children and young adults compiled by Natalia Paprocka and it summarises the most important assumptions of her research: she applied the concept of the literary field of Pierre Bourdieu, the notions of import/transfer and culture repertoire as understood by Itamar Even-Zohar, and Bruno Latour's actornetwork theory. According to the researcher, throughout the entire century, Polish publishers chose the strategies of re-releases of the classics, which significantly reduced the transfer of innovative phenomena of French children's culture.

Key words:

agent, bibliography, France, children's book illustration, children's and young adult literature, French literature, Natalia Paprocka, literary field, Poland, translation, reception, culture repertoire, book market, translator, transfer, editor

rzekład tekstu literackiego to zjawisko o fundamentalnym znaczeniu dla kultury docelowej; literatura tłumaczona może w pewnych okolicznościach znaleźć się w samym centrum systemu literackiego i odegrać kluczową rolę w kształtowaniu repertuaru kultury rodzimej. Ta szeroko spopularyzowana dziś teza Itamara Evena-Zohara (1978/2009, s. 198-199) leży u podstaw badań, których autorzy starają się powiedzieć coś nowego o kulturze rodzimej dzięki spojrzeniu przez pryzmat obecnych w niej przekładów. Z wielu 
względów słuszność tego podejścia narzuca się z całą oczywistością zwłaszcza wtedy, gdy przedmiotem zainteresowania jest literatura dziecięca, której teksty od najdawniejszych początków były tworzone z figur, fabuł, konwencji i tematów przekraczających bez trudu granice państw narodowych.

Coś nowego o polskiej kulturze literackiej dla dzieci i młodzieży mówi także Natalia Paprocka (2018a, 2018b), przedstawiając historię polskich przekładów i adaptacji francuskiej literatury dziecięcej w ostatnim stuleciu. Przeprowadzone przez nią badania miały dwuetapowy przebieg, a ich rezultaty zostały zaprezentowane w dwóch książkach: Bibliografia polskich przekładów i adaptacji francuskiej literatury dla dzieci i młodzieży wydanych w latach 19182014 i Sto lat przekładów dla dzieci i młodzieży w Polsce. Francuska literatura dla młodych czytelników, jej polscy wydawcy i ich strategie (1918-2014).

Pierwszą częścią pracy było zestawienie bibliografii polskich tłumaczeń i adaptacji francuskich utworów literackich dla dzieci i młodzieży, opublikowanych w formie druków zwartych (ewentualnie części druków zwartych) na terenie Rzeczpospolitej Polskiej lub Polskiej Rzeczpospolitej Ludowej w okresie ograniczonym datami 1918-2014 (ostatni rok, dla którego pełne źródła były dostępne w momencie układania bibliografii; Paprocka, 2018a). Na tym etapie autorka przyjęła założenia, które trzeba pokrótce wymienić, by ułatwić zrozumienie kształtu książki: po pierwsze Natalia Paprocka zestawiła bibliografię publikacji należących do kategorii „literatury pięknej dla dzieci i młodzieży" zgodnie z definicją przyjętą przez polską Bibliotekę Narodową. Definicja ta obejmuje m.in. książki obrazkowe, ale wyklucza pewne grupy tekstów, w szczególności komiksy, co sprawia, że w zestawieniu bibliograficznym znajdziemy książki Hervégo Tulleta (s. 248), ale nie ma w nim Asteriksa Renégo Goscinny’ego i Alberta Uderzo. Po drugie, w razie wątpliwości, o uznaniu tekstu za przeznaczony dla dzieci i młodzieży decydował adres czytelniczy sygnalizowany przez polskich wydawców, dlatego znalazły się w bibliografii utwory zarówno św. Teresy od Dzieciątka Jezus (s. 245) jak i Alexandre’a Dumasa (s. 106-114). Po trzecie, za francuskie uznano książki, których oryginalne wersje powstały w języku francuskim i zostały opublikowane we Francji, dlatego w zestawieniu nie znajdziemy francuskojęzycznych tekstów wydanych np. w Belgii, obecne są w nim natomiast książki o słoniu Pomelo Rumunki Ramony Bădescu (s. 38-39).

Łącznie w zestawionej przez Natalię Paprocką bibliografii znalazło się 1905 jednostek - wydań, zarówno tłumaczeń, jak i adaptacji, przedstawionych w układzie alfabetycznym według haseł autorskich twórców tekstów oryginalnych. Ze względu na płynność rozróżnienia tłumaczenia i adaptacje nie zostały wyodrębnione. Zestawienie uzupełniono trzema indeksami: osób, serii 
wydawniczych i tytułowym. Praca ta, wykonana z dużą starannością i troską o przejrzystość prezentacji wyników, jest bardzo cenna i z pewnością będzie służyć pomocą osobom prowadzącym badania w zakresie co najmniej kilku różnych dyscyplin.

$\mathrm{Na}$ podstawie zebranych danych bibliograficznych Natalia Paprocka (2018b) przeprowadziła drugi etap badania, którego wyniki przedstawiła w książce Sto lat przekładów dla dzieci i młodzieży w Polsce. Francuska literatura dla młodych czytelników, jej polscy wydawcy i ich strategie (1918-2014). Jest to książka, która łączy w funkcjonalną całość kilka różnych perspektyw. Autorka podejmuje badania nad obecną w Polsce francuską literaturą dla dzieci i nad związanym z nią wycinkiem rynku książki w ostatnim stuleciu, stosując złożone instrumentarium, na które składają się elementy nauki o literaturze, przekładoznawstwa, bibliologii i socjologii. Pod względem koncepcyjnym praca jest, w moim przekonaniu, bardzo starannie przemyślana, co zasługuje na podkreślenie ze względu na dużą różnorodność zastosowanych w niej strategii. Efekt złożonej, ale spójnej całości, wolnej od chaosu wywołanego nadmiernym eklektyzmem, został osiągnięty za sprawą wyważonego podejścia interdyscyplinarnego, w najlepszym znaczeniu tego szeroko rozumianego terminu.

Charakterystyczną cechą projektu jest swego rodzaju paradoksalność, wynikająca z szacunku, którym autorka darzy przedmiot swoich badań - mamy do czynienia z analizą „małego” tematu, dokonaną przy użyciu potężnych narzędzi. Zakres tematyczny i cel pracy wydaje się skromny (Natalia Paprocka chce przebadać funkcjonowanie stosunkowo niewielkiej grupy na ogół niezbyt wpływowych tekstów), a przywoływane konteksty kulturowe oraz stosowane instrumentarium - bardzo rozległe. Rezultatem takich założeń wstępnych jest pisanie z naddatkiem, bo w rzeczywistości książka przynosi o wiele więcej, niż obiecuje tytuł: mówi znacznie szerzej zarówno o literaturze francuskiej, jak i o polskiej kulturze dziecięcej, a przy tym zawiera kapitalne fragmenty, przemycone chyłkiem i schowane jak prezenty pod poduszką. Jest to praca napisana ze szczodrą dokładką treści, osadzająca omawiane zjawiska w szerokim i ciekawie zinterpretowanym kontekście. Wydane w Polsce francuskie książki dla dzieci wchodzą w liczne alianse - miłośnik książki obrazkowej dowie się np. sporo o historii francuskich albums, czytelnik, którego ciekawi życie literackie w PRL-u, dostanie barwny rozdział o cenzurze ( $\mathrm{z}$ wypisami z recenzji tworzonych na ulicy Mysiej), a odbiorca zainteresowany socjologią sztuki zapozna się z mniej znanymi w Polsce, nietłumaczonymi wypowiedziami francuskich myślicieli, przede wszystkim Pierre’a Bourdieu.

Książka Sto lat przekładów... składa się z czterech rozdziałów. Pierwszy $\mathrm{z}$ nich, Uwagi wstępne, zawiera przedstawioną wyżej charakterystykę projektu 
oraz zwięzły opis dziejów literatury dla dzieci we Francji i w Polsce od najdawniejszych początków do schyłku XIX wieku. Ponadto autorka referuje (skromny) stan polskich badań nad francuską literaturą dziecięcą.

Zarys najdawniejszej historii francuskiej literatury dla dzieci obejmuje kwestie także w Polsce bardzo dobrze znane, natomiast dalsze losy francuskiego piśmiennictwa dla najmłodszych są z punktu widzenia polskiego czytelnika rozpoznane znacznie słabiej. Natalia Paprocka poświęca więc nieco uwagi dydaktycznej literaturze drugiej połowy XVIII i początków XIX wieku, pisze o rozwoju powieści dla młodych odbiorców, wskazuje (w połowie XIX stulecia) początek różnicowania dziecięcego czy telnika i czytelniczki ze względu na płeć, wymienia działające we Francji czasopisma i serie wydawnicze, omawia XIX-wieczne początki francuskiej książki obrazkowej i komiksu. Przełom XIX i XX stulecia opisuje jako moment zapaści francuskiej książki dla dzieci i schyłek złotego wieku, po którym rozpoczęła się trwała dominacja obcej, zwłaszcza angielskojęzycznej literatury dziecięcej.

W Uwagach wstępnych znajdziemy także zwięzły podrozdział poświęcony polskiej literaturze dla dzieci przed rokiem 1918; zawiera on interesujące informacje na temat zasięgu i niezwykle silnego oddziaływania przekładów z języka francuskiego na polską literaturę dla dzieci przed pierwszą wojną światową. Transfer literatury dziecięcej z Francji rozwinął się już w XVIII wieku, na długo przed ukształtowaniem się polskiej twórczości dla czytelników niedorosłych, i pozostał silnym czynnikiem kulturotwórczym do końca wieku XIX. Trudno zatem przecenić rolę, jaką przekłady z języka francuskiego (a nawet tylko zapośredniczone przez francuski teksty literatury dziecięcej innych narodów) odegrały w kształtowaniu polskich konwencji. Prekursorskie oddziaływanie literatury francuskiej na polską wyrażało się m.in. w natychmiastowej recepcji obszernego korpusu francuskojęzycznych tekstów, co zwraca uwagę zwłaszcza w odniesieniu do twórczości Jules’a Verne’a. Zmiana kierunku zapożyczeń dokonała się na przełomie stuleci i była m.in. następstwem kryzysu francuskiej literatury dla dzieci oraz dynamicznego rozwoju literatur anglojęzycznych; literatura francuska nigdy już nie miała się zbliżyć do rangi, jaką miała w Polsce w wieku XIX.

Kolejny podrozdział Uwag wstępnych poświęcony jest polskim badaniom nad francuską literaturą dziecięcą. Budziła ona znacznie mniejsze zainteresowanie badaczy niż studia nad przekładem, prowadzone w ramach rozwijającej się prężnie i zyskującej autonomię translatoryki literatury dziecięcej. W ten ostatni nurt wpisują się także badania Natalii Paprockiej, którą wyróżnia zainteresowanie postacią wydawcy jako agenta w polu literackim: kluczowym obszarem jej badań są decyzje polskich wydawców dotyczące selekcji 
publikowanych tekstów. Książka nie analizuje w zasadzie strategii tłumaczeniowych wybieranych przez polskich tłumaczy literatury francuskiej, nie poddaje zatem refleksji relacji między tą literaturą $\mathrm{w}$ oryginale i w tłumaczeniu. Centralną postacią jest zamiast tego wydawca, figura, która przykuwa uwagę translatologów stosunkowo rzadko. Trudno jednak nie zgodzić się z autorką, jeśli chodzi o ocenę wpływu wydawców na życie literackie, choć postać ta pomijana jest często w badaniach, zwykle zorientowanych na autora (czy autorów) albo na odbiorcę. Książka Paprockiej jest przykładem trzeciej drogi: publisher-orientedness (Paprocka, 2018b, s. 37). Przyjęte przez autorkę założenia wpisują jej refleksje w nurt badań bibliologicznych.

Pozostałe narzędzia stosowane $\mathrm{w}$ analizie uzyskanego materiału bibliograficznego zostały scharakteryzowane w kolejnej części, zatytułowanej Inspiracje. Ramy refleksji podejmowanej przez autorkę zostały zakreślone bardzo szeroko za sprawą przyjętej przez nią definicji przekładu, który jest tu pojmowany jako społeczne wydarzenie tłumaczeniowe (translation event, a nie translation act) zgodnie z rozróżnieniem Gideona Toury’ego, co pozwala na podkreślenie sprawczej roli wydawcy przekładu (Paprocka, 2018b, s. 59-61). Źródłem najbardziej produktywnych narzędzi analitycznych jest jednak dla autorki francuska socjologia sztuki Pierre'a Bourdieu. Teoretyk ten jest w Polsce popularny i szeroko znany. Jego siatka pojęciowa, w formie zaczerpniętej przede wszystkim z książki Reguły sztuki. Geneza i struktura pola literackiego (1992/2007), została stosunkowo niedawno wykorzystana w obszernych badaniach najnowszej literatury polskiej przeprowadzonych przez zespół kierowany przez Piotra Mareckiego (Jankowicz, Marecki, Palęcka, Sowa, Warczok, 2014). Natalia Paprocka sięga oczywiście po pojęcia integralnie związane z całością koncepcji Bourdieu, takie jak: pole literackie, kapitał ekonomiczny i symboliczny, konsekracja i autonomia, strategia krótko- i długoterminowa. Jej autorskim wkładem w poszerzanie polskiej recepcji Bourdieu jest jednak adaptacja dyskutowanego przez translatologów pojęcia pola przekładowego, a także przywołanie jeszcze niewyeksploatowanych obszarów refleksji francuskiego socjologa i prac nietłumaczonych dotąd na język polski, zwłaszcza Une révolution conservatrice dans l'édition [Rewolucja konserwatywna w edytorstwie] (Bourdieu, 1999).

W artykule o „rewolucji konserwatywnej” Bourdieu (1999) wypowiada się na temat francuskich wydawców i analizuje strukturę pola wydawniczego [champ éditorial], w którym pozycja wydawcy koreluje z podejmowaną przez niego strategią, rozpiętą między dwoma biegunami: całkowitego podporządkowania się oczekiwaniom rynku - co oznacza reprodukowanie akceptowanych społecznie form sztuki i umożliwia gromadzenie kapitału ekonomicznego 
- oraz całkowitej wolności i odrzucenia wymagań rynku - co jest tożsame z przyjęciem strategii „antyekonomicznej”, która umożliwi wydawcy akumulację prestiżu (kapitału symbolicznego; Bourdieu, 1999, s. 6-15). Koncepcja Bourdieu będzie wykorzystywana w kolejnych rozdziałach jako podstawowe narzędzie interpretacji zaobserwowanych przez autorkę zmian w polskim ruchu wydawniczym i decyzji wydawców przekładów, w odniesieniu do kultury literackiej II i III Rzeczpospolitej, przy czym zwłaszcza w odniesieniu do literatury tego drugiego okresu przyniesie interesujące rezultaty. Nie sposób natomiast zastosować teorii Bourdieu do analizy planowanej centralnie gospodarki PRL, zwłaszcza do sterowanego odgórnie i aktywnie nadzorowanego importu tekstów kultury zachodniej. Pomocą w tym zakresie stanie się inna koncepcja, współtworzona przez Francuza Brunona Latoura teoria aktora-sieci (ANT), którą Natalia Paprocka (2018b) wymienia jako trzecią spośród inspirujących ją metodologii.

Drugą z nich jest przełomowa koncepcja ściśle związana $\mathrm{z}$ translatologią - teoria Itamara Evena-Zohara (Paprocka, 2018b, s. 71-77). Wybór wydaje się oczywisty, skoro teoretyk ten patronuje ujęciu, które każe w literaturze tłumaczonej upatrywać probierza stanu polisystemu literackiego kultury docelowej. Warto jednak podkreślić, że i w tym zakresie Natalia Paprocka eksponuje mniej znane prace izraelskiego teoretyka, koncentrując uwagę na - bardzo użytecznym, jak się później okaże - pojęciu transferu. Występuje ono w opracowanej przez Evana-Zohara koncepcji repertuaru kulturowego, która w jego pracach stopniowo zastąpiła pojęcie polisystemu. Even-Zohar dostrzega w kulturze nie tylko przepływ dóbr, uważa ją także za funkcjonalny system narzędzi, tworzących repertuar kulturowy, używany przez członków danej społeczności do organizowania rzeczywistości humanistycznej. Nowe narzędzia w repertuarze bywają czasem wynajdywane, ale wielką rolę odgrywa także ich import. Zapożyczone $\mathrm{z}$ innych kultur dobra $\mathrm{w}$ chwili, gdy stają się narzędziami i wchodzą w skład repertuaru kulturowego, zamieniają się w transfer, a osoby czy zespoły, które wspierają ich funkcjonalizację, Even-Zohar nazywa agentami transferu; tych właśnie agentów Natalia Paprocka będzie poszukiwać wśród wydawców polskich książek dla dzieci.

Ze wspomnianej już teorii ANT w wersji Latoura Natalia Paprocka zapożycza przede wszystkim pojęcie aktora jako uczestnika procesu, którym jest tworzenie książki (Paprocka, 2018b, s. 81). Najciekawsze efekty autorka uzyska, przykładając tę kategorię poznawczą do działania cenzury w okresie PRL (s. 253-267).

Kolejna część, zatytułowana Sto lat francuskiej literatury dla dzieci i mło$d z i e z ̇ y$, również ma charakter kontekstowy, ale rozdział ten jest tak ciekawy 
i cenny, że warto wyszczególnić jego komponenty. Natalia Paprocka opisała w nim francuską literaturę dla dzieci od zakończenia pierwszej wojny światowej do czasów obecnych. Co znamienne, teksty tworzone dla dzieci w ostatnim stuleciu we Francji to w zasadzie tylko proza, inne typy literatury - nie licząc oczywiście książki obrazkowej - nie są reprezentowane. Na pierwszy rzut oka widać też różnicę periodyzacji: dla polskiej literatury dziecięcej Natalia Paprocka przyjmuje podział na trzy fazy - międzywojnie, PRL i okres po roku 1989 - natomiast literaturę francuską dzieli na cztery okresy. W porównaniu z sytuacją w Polsce, zmiany we francuskiej literaturze dla dzieci zachodziły znacznie płynniej, bez ostrych cięć, stanowiąc raczej odzwierciedlenie długofalowych procesów społecznych niż politycznych wstrząsów. Za Isabelle Nières-Chevrel Natalia Paprocka (2018b) wskazuje cztery fazy rozwoju francuskiej literatury dla dzieci. Pierwszą z nich jest okres międzywojenny, nisko na ogół oceniany ze względu na zastój wyrażający się w dużej liczbie adaptacji i wznowień literatury dziewiętnastowiecznej, ale niepozbawiony ważnych dokonań, wśród których trzeba przede wszystkim wskazać narodziny awangardowej książki obrazkowej.

Najciekawsze zjawiska pączkujące w latach międzywojennych rozkwitły w kolejnej fazie, nazywanej wspaniałym trzydziestoleciem (1945-1975). Rozwój literatury dziecięcej podążył w tym czasie za wzrostem gospodarczym i odczuwalnymi w całej Europie Zachodniej przemianami mentalności, których symbolem może być utworzenie International Board on Books for Young People (IBBY). We Francji w tym okresie rozwijały się dynamicznie wydawnictwa kierujące swą ofertę do dzieci, a pod koniec trzydziestolecia powstawały także oficyny o dużych ambicjach artystycznych; publikowano rozbudowane serie wydawnicze, wciąż wznawiano klasykę i tłumaczono literaturę obcą, a nawet rodzima produkcja literacka czerpała $\mathrm{z}$ amerykańskich inspiracji, np. w bardzo popularnej w tym okresie rozrywkowej powieści kryminalnej. Zaznaczyły się jednak również charakterystyczne dla Francji oryginalne tendencje - wysoko oceniana realistyczna powieść obyczajowa, często $\mathrm{z}$ wnikliwie zarysowanym dziecięcym bohaterem/narratorem, ceniona literatura fantastyczna i baśń literacka, dziecięca proza humorystyczna, znakomita książka obrazkowa. W okresie tym, zwłaszcza w latach 70., wyraźnie zaznaczył się we Francji nurt feministyczny w literaturze adresowanej do dziewczynek. We wspaniałym trzydziestoleciu, szczególnie w dobie ruchów kontestacyjnych, kryzysu związanego $\mathrm{z}$ wojną $\mathrm{w}$ Wietnamie i buntu studentów, zauważyć dało się postępujące osłabienie autorytetu dorosłych, zmierzające czasem do jawnej antagonizacji dziecka i dorosłego. Francuski „kompleks mentora” charakterystyczny dla omawianego okresu przypomina zjawiska, do których w polskiej prozie dla dzieci miało dojść mniej więcej trzy dekady później (Leszczyński, 2001). 
Trzeci z wyróżnionych przez Isabelle Nières-Chevrel okresów to ostatnie ćwierćwiecze XX wieku, gdy we francuskiej literaturze dla dzieci ujawniły się tendencje widoczne dziś w Polsce. Można wśród nich wymienić np. dziecięcą odmianę literatury faktu, najczęściej poruszającą temat drugiej wojny światowej i Zagłady; utwory przedstawiające trudne i traumatyzujące dla dziecka relacje $\mathrm{w}$ dysfunkcyjnej rodzinie, a $\mathrm{z}$ drugiej strony literaturę obyczajową z elementami humoru i satyry, mającej na celu zrelatywizowanie autorytetu dorosłych, ze szczególnym naciskiem na „dekonstrukcję” postaci ojca. W tym okresie nadal intensywnie rozwijała się francuska książka obrazkowa. Jej dalsze przemiany, często związane $z$ detabuizacją tematów wykluczanych wcześniej z kultury dziecięcej, są charakterystyczne także dla najnowszej francuskiej literatury dla dzieci.

W czwartej fazie, obejmującej prozę XXI wieku, zaznacza się także wielka waga fantastyki, a ponadto gra konstrukcją narratora oraz nasilona intertekstualność.

Główna część książki to charakterystyka polskich przekładów francuskiej literatury dla dzieci. Losy literatury tłumaczonej zostały przedstawione odrębnie dla każdego $\mathrm{z}$ analizowanych okresów, mamy więc osobne rozdziały poświęcone dwudziestoleciu międzywojennemu, literaturze okresu PRL oraz najnowszej, po roku 1989. Każdy rozdział ma identyczną strukturę: przedstawiono w nich syntetyczny opis sytuacji na rynku książki, charakterystykę aktywnych w danym okresie wydawców książki dziecięcej, procentowy udział książek tłumaczonych z języka francuskiego w całej produkcji literackiej dla dzieci i młodzieży, wybory wydawców (to bardzo ciekawe dane, wskazujące, jakie utwory i których pisarzy wydawano najczęściej) ${ }^{1}$ i wreszcie interpretację

1 Podam kilka danych liczbowych, ujmując je w przekroju (Paprocka, 2018b, s. 355): liczba wydań literatury tłumaczonej z języka francuskiego wynosiła w dwudziestoleciu międzywojennym 252 (ponadto 13 książek ukazało się w czasie wojny), czyli średnio nieco ponad 11 książek rocznie; liczba ta stanowiła $3 \%$ całej produkcji literackiej dla dzieci i młodzieży. Język francuski usytuował się na drugim miejscu, za angielskim, z którego tłumaczono coraz bardziej intensywnie (dysproporcja rosła w całym badanym okresie). W latach 1945-1989 ukazało się w Polsce 355 wydań francuskiej literatury dla dzieci, średnio niespełna 8 wydań w każdym roku, choć edycje te rozkładały się nieproporcjonalnie - były najliczniejsze w okresie odwilży październikowej i pod koniec lat 80. Literatura francuska stanowiła w okresie PRL (właściwie w latach 1955-1989, dla których dostępne są dane „Ruchu Wydawniczego w Liczbach”) 1,9\% całej produkcji literackiej dla młodych odbiorców, a francuski uplasował się w tym okresie na czwartej pozycji (za angielskim, rosyjskim i niemieckim). Według danych z lat 1989-2014 w III Rzeczpospolitej język francuski ponownie znalazł się na miejscu drugim, za angielskim (udział tych dwóch języków w rynku książki 
strategii wydawców (tu jako narzędzia opisu posłużyły koncepcje Bourdieu, Evena-Zohara i Latoura).

Najczęściej publikowani w okresie międzywojennym pisarze francuscy to twórcy formacji dziewiętnastowiecznej, którzy w 1918 roku należeli już do klasyki. Na czele listy znajduje się Jules Verne z liczbą 92 wydań, ogólnie zresztą dominuje powieść przygodowa. Wydawano wprawdzie w Polsce także utwory współczesnych pisarzy francuskich, ale byli to zapomniani obecnie twórcy, którzy w swojej ojczyźnie nie wywarli istotnego wpływu na przemiany literatury dziecięcej. W tłumaczeniach pojawia się również baśń literacka oraz literatura religijna. Analizując strategie wydawców międzywojennych, Natalia Paprocka podkreśla wyrazistą tendencję do wznawiania bezpiecznej i dochodowej klasyki. Podobny obraz rysuje się w jej analizie pola literackiego w rozumieniu Bourdieu (strategia gromadzenia kapitału ekonomicznego) i repertuaru kulturowego Evena-Zohara (literatura francuska nie stanowiła istotnego transferu). Jako główni aktorzy przedstawieni są tłumacze, których wkład w powstawanie książek był różnicowany przede wszystkim ze względu na strategię wydawnictwa.

W latach 1945-1989 dominacja Verne’a nie osłabła; kolejne pozycje zajmowali w tym okresie: Alexandre Dumas, Charles Perrault, Victor Hugo i Antoine de Saint-Exupéry. Ruch literacki sterowany był wówczas przez państwo, a w latach 50. obok nadzoru produkcji literackiej pojawił się plan celowego niszczenia księgozbiorów. Natalia Paprocka wnikliwie analizuje mechanizmy eliminacji francuskich książek dla dzieci, opisując oba zjawiska w kategoriach celowego formowania repertuaru kulturowego. Wykorzystując koncepcję Latoura, autorka zauważa i opisuje nowych aktorów działających w procesie przekładu - cenzorów i twórców agitacyjnych paratekstów.

Po zmianie ustroju w 1989 roku najczęściej publikowanym francuskim pisarzem pozostał Verne, ale najchętniej wydawanym tytułem był Mały Ksiażę. Spadła popularność Hugo, wzrosła - Perraulta. Nowym nazwiskiem wśród najpopularniejszych stał się, za sprawą serii o Mikołajku, René Goscinny. Wśród strategii opisywanych w kategoriach Bourdieu najsilniej zaznaczyła się logika ekonomiczna, zwłaszcza w działalności wydawnictw produkujących kilkustronicowe książeczki dla najmłodszych, na ogół z minimalną zawartością tekstu i schematycznymi, barwnymi ilustracjami. Na rynku książki znalazło się także wiele wznowień, zwłaszcza drukowanych w dużej liczbie lektur szkolnych, a więc dzieł należących do klasyki. Przeciwną tendencję można

dla dzieci dzieli jednak przepaść ponad 6 tysięcy tytułów). Opublikowano 1285 wydań książek tłumaczonych z języka francuskiego, co stanowiło nieco ponad 6\% produkcji. 
jednak zauważyć w działalności małych oficyn awangardowych, znanych jako „wydawnictwa lilipucie”, dążące wyłącznie do wprowadzenia na rynek książek wybitnych (obecnie są to głównie książki obrazkowe).

Warto wspomnieć, że wydawcy lilipuci są powracającym tematem badań Natalii Paprockiej, która poświęciła tej grupie oficyn wiele uwagi w książce napisanej wraz z Katarzyną Biernacką-Licznar oraz Elżbietą Jamróz-Stolarską (2018): Lilipucia rewolucja. Awangardowe wydawnictwa dla dzieci i młodzieży w latach 2000-2015. Produkcja wydawnicza. Bibliografia. Monografia ta opisuje historię powstania i rozwoju polskich wydawnictw lilipucich, przedstawia charakterystykę ich produkcji wydawniczej i wyniki analizy bibliometrycznej ich dorobku (z uwzględnieniem miejsca i roli literatur obcych w przekładzie na język polski), a także opis publikowanych przez wydawnictwa lilipucie książek ze względu na elementy składające się na ich architekturę. Praca ta również zawiera bibliografię obejmującą łącznie 15 lat działalności 16 oficyn, które opublikowały w badanym okresie 851 tytułów. O poznawczej atrakcyjności książki decyduje także znacząca rola wywiadów, które autorki przeprowadziły z twórcami wydawnictw, omawiając kontekst ich doświadczeń związanych nie tylko z działalnością wydawniczą, ale także z życiem prywatnym - przyjaźniami, wychowywaniem dzieci, osobistymi dążeniami i planami. Książka ta różni się bardzo od Stu lat przekładów..., ale trzeba podkreślić, że niezależnie od wyboru zupełnie innej konwencji jest to również praca poświęcona kulturotwórczej roli wydawców i skonstruowana $\mathrm{z}$ zastosowaniem starannie przemyślanej i konsekwentnie stosowanej metodologii.

$\mathrm{Na}$ zakończenie chciałabym pokreślić wielką zaletę książek Natalii Paprockiej: badaniom literatury dla dzieci zagrażają, moim zdaniem, dwie słabości, i obu tych niebezpieczeństw autorka bardzo skutecznie unika dzięki konsekwentnemu stosowaniu jasno określonych założeń. Pierwszą mielizną, do której nigdy się nie zbliża, jest ogólnikowość i nieprecyzyjność twierdzeń, formułowanych na podstawie domniemań, bez rzetelnego rozpoznania i bez troski o wybór i stosowanie adekwatnych metod. Drugim problemem (wynikającym do pewnego stopnia z pierwszego) jest dydaktyzm, wyrazisty zwłaszcza u tych badaczy, którzy - akceptując konserwatywny model pedagogiki uważają dziecko przede wszystkim za wychowanka dorosłych. Wiąże się to $\mathrm{z}$ łatwym, niemal nieświadomym przekraczaniem granicy oddzielającej naukę o literaturze od krytyki literackiej za sprawą formułowania sądów wartościujących. W książce Paprockiej nie znajdziemy prostych ocen ani słabo umotywowanych tez; walorem tej pracy jest staranne dokumentowanie wszystkich spostrzeżeń i obiektywizm. 
Przypuszczam, że poszczególne części książki mogą być interesujące dla różnorodnych czytelników. Znaczną część będą moim zdaniem stanowić polscy frankofoni, którzy (jak pisząca te słowa) nie są z wykształcenia romanistami, i których lektura Stu lat przekładów... zachęci prawdopodobnie do poszukiwań wartościowych francuskich książek nieprzetłumaczonych dotąd na język polski. Ci właśnie czytelnicy odczują pewnie niedosyt wynikający z lapidarności rozdziału, który autorka poświęciła literaturze francuskiej ostatniego stulecia. Jest to zwięzłość zupełnie zrozumiała, bo w całej koncepcji monografii rozdział ten jest jedynie kontekstem i ma na celu zarysowanie tła, ale zagadnienia $\mathrm{w}$ nim poruszone są $\mathrm{w}$ moim przekonaniu tak potrzebne i wartościowe dla polskiego czytelnika, że bardzo wskazane byłoby ich rozwinięcie i wyeksponowanie, może w kontekście inaczej sprofilowanej publikacji lub w formie oddzielnego artykułu. Francuskiej literatury dla dzieci nie analizują na ogół ani poloniści, ani romaniści, a jej reprezentacja w badaniach jest niezwykle skromna i bardzo fragmentaryczna; znaczące obszary tej literatury, często nietłumaczone lub wydane w niewielkich nakładach, nie docierają do polskiej publiczności literackiej.

Szerokie zainteresowanie wzbudza w zasadzie tylko najdawniejsza tradycja dworskiej baśni; w publikacjach i wystąpieniach konferencyjnych powracają nazwiska Perraulta, twórczyń contes de fées, Marie Catherine d’Aulnoy i Jeanne-Marie Leprince de Beaumont, $\mathrm{z}$ innych względów tworzącego ad usum Delphini Fénelona, z jeszcze innych - La Fontaine’a. Mniej obecne w badaniach, szerzej chyba w świadomości społecznej, są różne odmiany francuskiej powieści przygodowej, na ogół dziewiętnastowiecznej, co sprawia, że na polski obraz francuskiej literatury dla dzieci składają się przede wszystkim utwory pochodzące z odległej już przeszłości. Zestawienie to uzupełnia pewna liczba cenionych w Polsce tekstów, które określiłabym mianem „mądrościowych”. Jest to przede wszystkim Mały Książe, utwór znakomity i bogaty w znaczenia, ale $\mathrm{w}$ doświadczeniu polskich czytelników zinterpretowany w duchu szkolnej liturgii jako skarbnica dydaktycznych komunałów. Problemy związane z samotnością, śmiercią i kształtowaniem humanistycznego systemu wartości łączą w świadomości Polaków (wrażenie to podsycają parateksty wydawnicze) utwór Saint-Exupéry’ego, opowieść Michela Déona (2010) Tomek i nieskończoność oraz - przedstawioną w stylu znacznie mniej podniosłym - historię umierania chłopięcego bohatera powieści Erica-Emmanuela Schmitta (2004) Oskar i pani Róża. Ostatni wreszcie krąg dobrze przyjmowanej literatury dziecięcej to reprezentowana przez cykl o Mikołajku humorystyczna opowiastka obyczajowa, ale ogólnie rzecz biorąc obecność dziecięcej literatury francuskiej w Polsce jest - używając sformułowania Evena-Zohara (1978/2009) - „czynnikiem konserwatyzmu” (s. 202). 
Z badań Paprockiej wyłania się natomiast optymistyczna wizja recepcji francuskiej książki obrazkowej; w ciągu kilku lat dzielących nas od roku 2014, na którym zakończyła się zestawiona przez autorkę bibliografia, ruch wydawniczy potwierdza, jak się wydaje, zarysowane w badaniu tendencje.

\section{Bibliografia}

Biernacka-Licznar, K., Jamróz-Stolarska, E., Paprocka, N. (2018). Lilipucia rewolucja. Awangardowe wydawnictwa dla dzieci i młodzieży w latach 2000-2015. Produkcja wydawnicza. Bibliografia. Warszawa: Wydawnictwo Naukowe i Edukacyjne SBP.

Bourdieu, P. (1999). Une révolution conservatrice dans l'édition. Actes de la recherche en sciences sociales, 126-127, 3-28. https://doi.org/10.3406/arss.1999.3278.

Bourdieu, P. (2007). Reguly sztuki. Geneza i struktura pola literackiego (A. Zawadzki, tłum.). Kraków: TAiWPN Universitas. (wyd. oryg. 1992).

Déon, M. (2010). Tomek i nieskończoność (M. Kusztelska, tłum.). Poznań: Oficyna Wydawnicza G\&P. (wyd. oryg. 1975).

Even-Zohar, I. (2009). Miejsce literatury tłumaczonej w polisystemie literackim (M. Heydel, tłum.). W: P. Bukowski, M. Heydel (red.), Współczesne teorie przekładu. Antologia (s. 197-203). Kraków: Znak. (wyd. oryg. 1978).

Jankowicz, P., Marecki, P., Palęcka, A., Sowa, J., Warczok, T. (2014). Literatura polska po 1989 roku w świetle teorii Pierre’a Bourdieu. Raport z badań. Kraków: Korporacja Ha!art.

Leszczyński, G. (2001). Kompleks mentora. Powieść dla młodzieży u schyłku tysiąclecia. W: A. Baluch, K. Gajda (red.), Sezamie, otwórz się! Z nowszych badań nad literatura dla dzieci i młodzieży w Polsce i za granica (s. 52-65). Kraków: WN AP.

Paprocka, N. (2018a). Bibliografia polskich przekładów i adaptacji francuskiej literatury dla dzieci i młodzieży wydanych w latach 1918-2014. Kraków: TAiWPN Universitas.

Paprocka, N. (2018b). Sto lat przekładów dla dzieci i młodzieży w Polsce. Francuska literatura dla młodych czytelników, jej polscy wydawcy i ich strategie (1918-2014). Kraków: TAiWPN Universitas.

Schmitt, E.-E. (2004). Oskar i pani Róża (B. Grzegorzewska, tłum). Kraków: Znak. (wyd. oryg. 2002). 